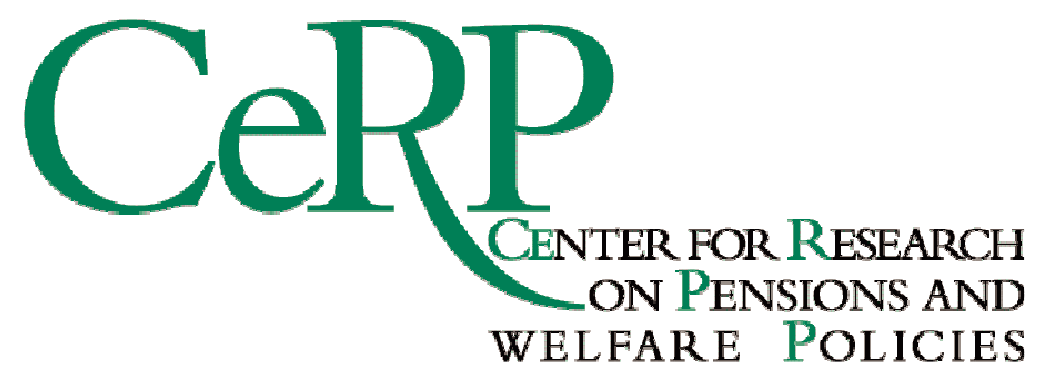

Working Paper 156/16

\title{
FINANCIAL INCLUSION AND LIFE INSURANCE DEMAND; EVIDENCE FROM ITALIAN HOUSEHOLDS
}

\author{
Elisa Luciano \\ Mariacristina Rossi \\ Dario Sansone
}




\title{
Financial Inclusion and Life Insurance Demand; Evidence from Italian households *
}

\author{
by \\ Elisa Luciano ${ }^{1}$ \\ Mariacristina Rossi ${ }^{2}$ \\ Dario Sansone ${ }^{3}$
}

November 2015

\begin{abstract}
This paper studies the demand drivers for life insurance, both lump sum and annuity, using the Bank of Italy (SHIW) panel dataset 2004-2012. We consider both participation and invested amounts. We use stock market participation, home ownership and financial literacy as measure of financial market inclusion. We find that financial inclusion stands as the pivotal regressor in shaping life insurance demand, especially annuities, even when we include pension funds in the definition of annuities. Instead, except gender, the traditional drivers of insurance demand, such as income, wealth, geographical or sociological variables, have a lower impact than financial inclusion. These results are robust to the inclusion of time and individual fixed effects, as well as the IV approach to tackle the potential endogeneity of financial inclusion.
\end{abstract}

\footnotetext{
* The Authors thanks participants to the Second Cintia Conference 2014, the ILO Summer School on Gender, Economics and Society 2015, the EFMA Conference 2015, the Paris-Dauphine Workshop on Pensions 2015, the Workshop on Household Finance, Luxembourg 2015, for comments and suggestions. They are grateful to Agar Brugiavini, Pierre Andrè Chiappori, Allison Stashko, Bart Dirtis and Arthur Van der Soest for helpful comments. Discussions with J.F. Outreville on a companion paper are also gratefully acknowledged. Zeist. We thank the EU MOPACT Grant n. 320333 and Netspar for funding.
}

\footnotetext{
${ }^{1}$ University of Turin, Collegio Carlo Alberto and Netspar Contact: elisa.luciano@unito.it;

${ }^{2}$ University of Turin, Collegio Carlo Alberto, LISER Netspar. Contact: mariacristina.rossi@unito.it

${ }^{3}$ Georgetown University. Contact: ds1289@georgetown.edu
} 


\section{Introduction}

Among all forms of savings, life insurance has a distinctive feature: it permits to distinguish long-term savings from straightforward bequest intentions. Indeed, the socalled pure life insurance, be it in the form of an annuity or in the form of a lump-sum amount, which can be withdrawn or converted into an annuity by the insured, represents a form of long-term savings. Life insurance protects against the risk of longevity, especially when it comes as an annuity. As a complement to it, term insurance, which pays in case of death of the insured, isolates bequest intentions. Separating pure life from term insurance we can pick savings intentions which are not directed towards bequest. For the sake of simplicity, we call life insurance "pure-life".

Despite the great potential of life insurance and being a pivotal part of household saving strategy, little attention has been paid to the empirical study of its demand. This lack of research interest is particularly surprising, also in light of steadily increasing over the last decade, in Europe as well as in the rest of the world, with a slight slowdown during the Great Recession only.

Italy stands out as a good candidate to study the demand of life insurance since, together with Germany, the UK and France, it accounts for $70 \%$ of the overall premiums in Europe. It is also a paramount example of the important role of insurance among other forms of savings: the expected payments from insurance companies to households amount to $11.7 \%$ of the Italian households' total wealth (see Ania 2014). As a comparison, bonds represents $16 \%$, shares $23 \%$ and mutual funds $8 \%$ of it.

In order to analyze the drivers of insurance demand in Italy, we look at both the determinant and the magnitude of the insurance investment, when positive. Specifically, we make use of the Survey on Household Income and Wealth (SHIW) data, as collected by the Bank of Italy between 2004 and 2012. This unique survey allows us to investigate traditional drivers of demand, such as income, wealth, geographical and demographic variables, as well as newer ones, such as financial market inclusion. We use as proxies for the latter stock holding, home ownership and financial literacy since they all represent proximity to financial market. In a second stage, we recognize the potential endogeneity of financial market participation and try to address it by using parental capabilities, as measured by parents' managerial skills, as instruments. Finally, we increase the robustness of our results by exploiting the panel dimension of the dataset and controlling for time and individual fixed effects.

To anticipate our results, we show that the demand for insurance - both participation and invested amount, given participation - is correlated with the explanatory variables already pointed out in the literature. However, financial-market inclusion has a much bigger impact than the traditional drivers.

\footnotetext{
4 This class of products is compared to the so-called "mixed policies", which act as a life insurance together with term insurance.
} 
Italian workers have a compulsory annuitization given by public pensions. Nevertheless, non-workers run the risk of being under-annuitized. When we interpret life insurance as potential annuity, we can therefore investigate the amount of annuitization over and beyond public provisions, provided we control for annuitization in the form of private pension plans, which in few cases can be acquired by non-workers as well (individual, open and category). To do so, we include a robustness check using either the life insurance subscription or private pension plan subscription as a source of annuitization. Results of this investigation confirm the pivotal role of financial inclusion.

In all our specifications, an important feature of our analysis is the distinction between genders. Women - at least in Italy - have a low participation rate in the labor market, with only one woman out of two working, and would need more voluntary annuitization, on top of compulsory one, which kicks in only if they work or are the widows of a worker. At the same time, women are usually less financially included and more distant than men from financial markets and matters, i.e. less involved in stock or home ownership, and less financially literate. Therefore, we expect a lower demand for life insurance by women. Again, the risk for women of being under annuitized is a vulnerability hardly considered in the saving literature. Our results show that, even controlling for financial inclusion, in all forms, gender still plays a role, and lowers further their propensity to buy and the amount they buy, when they do.

We conclude that, all else equal, an effective way in which insurance demand can be further increased is by increasing financial awareness through market inclusion.

The outline of the paper is the following. Section 2 provides the conceptual background and reviews the existing literature on insurance demand. Section 3 presents the data and the related descriptive statistics. Section 4 is devoted to our empirical analysis: we present the estimation strategy, followed by the estimation results. Section 5 concludes.

\section{Conceptual Background}

Insurance can be very effective in helping individuals to smooth consumption and to manage savings over the life-cycle, thanks to the coexistence of pure life and term insurance, which represent respectively pure savings and the intention to bequeath. We focus on the former.

To examine the conceptual background of life insurance, we distinguish two strands of literature: the theoretical and empirical literature on annuitization on the one side, the empirical investigation of the drivers of insurance demand on the other. Indeed, there is a long standing tradition in the former literature, much less in the second.

The basic theoretical conceptualization of the demand for pure life insurance, in the form of annuities, is Yaari's model (1965). The optimal solution for the household is to subscribe to an annuity, so as to neutralize the risk of running out of wealth before death. All others equal, an annuity dominates the other investment solutions, as it incorporates the probability of survival. Hence, under Yaari's assumptions, which 
exclude any bequest desire, everyone should annuitize all wealth. This is in contrast with empirical evidence and generates the so-called annuity puzzle. However, the prediction of Yaari is evidently not tenable if people have intention to bequeath or in the presence of other insurance contracts. Indeed, Yaari's model has been extended by Lewis (1989) to incorporate preferences of dependents and more recently by Davidoff, Brown and Diamond (2005) including bequest motives and health insurance (unfairly priced). Nevertheless, in the latter paper the quest for annuities remains high even in the presence of alternatives. Inkmann et al. (2010) further extend the theoretical model of the demand for insurance to include annuities, term insurance, and bonds as well as stocks choices. They show that, once the demand for insurance has been embedded into an enlarged portfolio selection model, and once this model has been calibrated to real data from the UK elderly households (ELSA), the annuity puzzle almost disappears. Another important reason for observing low demand for voluntary annuitization could be the presence of compulsory annuitization, through state social security and private DB plans. The tapering effect of compulsory annuitization on insurance demand has been analyzed by Bernheim (1991), Brown et al. (2001) and Dushi and Webb (2004).

Even after taking the above considerations into account, the total number of insured individuals should be high, even in countries where annuitization is compulsory for the working population, if - as it happens in Italy - the number of non-working citizens is high. In spite of this, apart from the cases analyzed in Inkmann (2011), the general conclusion is that too little demand for life insurance, particularly annuities (Brown 2008), is actually observed. ${ }^{5}$

As far as the main determinants of life insurance are concerned, studies have traditionally included household income, tax treatment, education, life expectancy, young dependents' ratio, risk aversion, financial vulnerability, age.

A wide strand of literature has indeed focused on the importance of income to purchase life insurance (Lewis 1989). Beck and Webb (2003) find the same evidence for 60 countries, both developing and developed ones. Li et al (2007) find a strong effect of income on the demand for insurance for OECD countries. Their findings highlight that a $1 \%$ increase in aggregate income is associated with an increase of about 0.6 percent in life insurance sales. The results are in line with the literature (i.e. Lewis, 1989, Outreville 1996 and Beck and Webb 2003, among others). Overall, there is consensus that income is significant in shaping insurance demand.

Tax treatment, and specifically the heterogeneity of the tax treatment of insurance contracts, is, under some circumstances, relevant in shaping demand. For instance, the fact that in several countries the premiums are either tax deductible or tax-exempt should spur the demand with respect to other forms of savings with comparable gross

\footnotetext{
5 A simple reason for that may be that insurance products are overpriced. This argument does not apply as soon as risk aversion heterogeneity between insurance sellers and buyers is high enough to make the cum-loading reservation price of the former lower than that of the latter. This paper does not dig into overpricing of insurance products. It assumes that competition among insurance sellers is high enough to make premiums lower than the average buyer's reservation price.
} 
returns and risk profile. This is not the case of Italy, though, as already demonstrated in Jappelli and Pistaferri (2002). Further amendments to the Italian tax code, which rendered the tax advantage of insurance even smaller than at the time Jappelli and Pistaferri conducted their study, have reduced the bias in favor of insurance even more ${ }^{6}$. For this reason, in this paper we do not take into consideration any specific tax code provision, and content ourselves with using net income, instead of gross income, as an explanatory variable.

In addition to GDP, Sen (2008) used financial debt, savings per capita, dependency ratio, adult literacy, life expectancy and crude death rate, among others, to explain the demand for insurance for selected Asian countries and India. Using micro data, the author found a positive relationship not only between the demand for insurance and GDP, but also with savings and financial development. Adult literacy rate, life expectancy, and dependency ratio were also significant. Conversely, at the macro level, neither education nor life expectancy and young dependency ratio mattered for the insurance demand (see Beck and Webb, 2003).

The sign of the impact on insurance demand of higher life expectancy, when it is significant, is in principle ambiguous. Longer life expectancies should lead, on one hand, to lower mortality coverage costs and lower perceived need for mortality coverage. On the other hand, they should lead to higher savings channeled through life insurance products and annuities. Previous papers on life expectancy and insurance demand (Brown and Kim 1993, Outreville 1996) find that the empirical evidence points to a positive correlation between life expectancy and insurance penetration.

Traditionally, risk aversion is supposed to increase the demand for insurance, all others equal. On top of that, in a recent survey, Outreville (2014) focuses on risk aversion and general education stressing that the two variables can be strongly correlated. More riskaverse individuals are likely to choose lower educational level and thus lower insurance demand.

Bernheim et al. (2003) do not find evidence that financial vulnerability to a shock matters, even controlling for family composition and shocks, as well as the tax system. Financial vulnerability is a fuzzy concept: to pin it down, Bernheim et al. select the spouse death. Lin and Grace (2007) extend the analysis of financial vulnerability, defined as above, controlling for age. At any level of financial vulnerability, the older the household the lower the demand for life insurance. Vulnerability as measured by death matters because the contribution to family's welfare of the dead member disappears, be the contribution monetary or non-monetized, in terms of time and services. We do not investigate such shocks, because we do not have a proxy for non-monetary contributions. 
Up to our knowledge, the growing literature on financial literacy has not focused on the demand for life insurance. Financial literacy provides the ability to manage wealth and help avoiding the mis-management of resources, particularly at old age (Lusardi and Mitchell 2007 and 2011 and Brown 2008). It has been shown that financially illiterate households do suffer in terms of portfolio performance and wealth accumulation (Jappelli and Padula, 2013; Van Rooij et al. 2011), irrespective of whether they ask for professional financial advice or whether they discuss investment choices with friends and relatives. Financial illiteracy leads to underperformance mainly because of lower participation to the stock market and under diversification. Evidence is mixed, though: for example, Guiso and Viviano, in a recent paper (2013) highlight that even highly literate individuals tend to choose the dominated alternative in the market, suggesting that literacy may be a poor protection against financial mistakes. A priori, the effect of illiteracy on insurance could be stronger than in other savings instruments, since insurance contracts may have both a financial component, such as the presence of a minimum guaranteed return of a guaranteed capital, and a longevity one, since their payoff is linked to the event of death or survival of the subscriber.

In studying demand for insurance, we will keep track of both the dominant evidence for under-annuitization, and the somewhat mixed evidence on the traditional demand drivers. To the latter, we will add an investigation of the role of financial inclusion, as defined in the Introduction, i.e. including financial literacy.

\section{Data}

The data source we use for our empirical analysis is the Survey of Household Income and Wealth (SHIW) which is conducted every two years by the Bank of Italy. The SHIW dataset provides detailed information about Italian households ${ }^{7}$, including household composition and characteristics, income and employment variables, wealth and its components. To our purpose, we make use also of information on the type of insurance held and the amount of premium paid.

For our empirical analysis, we have exploited the waves between 2004 and 2012. In order to carry out our analysis, we selected a sample consisting of individuals aged between 25 and 65 that are either a household head or the head's spouse, where the head is self-stated, as the person who takes financial decisions. We exclude other relatives and children living in the household so as to focus on the couple (or single) decisions. Our final sample consists of around 7,500 individual-observations in each wave.

To provide descriptive statistics for the sample, we focus on the 2010 wave. As Table 1 in the Appendix shows, the probability of owning life insurance - which is the sample frequency - is close to $7 \%$, and it goes up to $20 \%$ if we include private pension funds, with an average premium of euros 1672 . As concerns the socio-economic variables, $48 \%$

\footnotetext{
A household is defined as a group of individuals related by blood, marriage or adoption and sharing the same dwelling. In the tables we have often shorten the term household with hh.
} 
of the interviewed individuals are women. Household heads are close to their fifties. A very small percentage (3\%) lives with a partner without being married, while $79 \%$ of the individuals in the selected sample are married. Among all household heads and spouses, $32 \%$ has a high school diploma, $15 \%$ also a bachelor degree or higher, with the rest - an astonishing 53\% - with less than a high school diploma. As concerns employment, close to $11 \%$ is inactive, which means that he or she does not participate in the job market (students, housewives, unemployed people) but is not retired. So, a high $89 \%$ has either labour income or a pension. The inactive percentage goes up to more than $18 \%$ if we consider women only. Thirteen percent of the sample is self-employed. The number of years in which household heads have been working is quite high, 23 , but consistent with the age and education profile of the sample. $18 \%$ of the household heads and spouses live in a medium city (20,000 to 40,000 inhabitants), $46 \%$ in a large one $(40,000$ to half a million), $9 \%$ in a mega city (more than half a million), while the rest live in urban conglomerates with less than 20,000 inhabitants. North and Centre Italy host around $66 \%$ of the respondents, with the rest living either in the South or in the Islands. In order to assess the effect of family composition, which is expected to affect the propensity to buy insurance, we exclude both the household head and its spouse from the following indicators. Given that, on average there is less than one member in the family who is below 25 years, with an even smaller percentage of members above 25 (less than a third). These numbers point to the small number of family members typical of Italian families, and come as no surprise. Similarly, the proportion of households with offspring outside the household, be them sons or daughters of the household head or his spouse, is $29 \%$. Last, if we look at wealth and income, average net individual income is 22,283 euro (median is 19,831), and it represents $60 \%$ of the household income. This shows that the person who takes financial decisions and his or her spouse are also the main income providers in the family. The median ration of individual net income over individual net wealth - which comprehends real and financial assets, net of debts - is around 0.09 .

Surprisingly, few households have stocks, around $8 \%$, which includes mutual funds, while a large majority, more than $70 \%$, owns a house. Again, this is typical of the Italian propensity to allocate wealth. Last, in a scale from 0 to 1 , the average self-stated risk aversion is 0.4 . The corresponding dummy takes the value one only if the respondent, in choosing among four levels of increasing returns with increasing risk, are tied to the safest solution ("low returns, but no risk of losing the invested capital"). We will come back to this measure after having described financial literacy in the sample. We will see that risk diversification as demonstrated by wealth allocation, risk understanding as appearing in the financial literacy questions and self-stated risk aversion sometimes provide contradictory signals.

Given the importance that financial literacy will play later, Descriptive 1 separates the percentage of household heads and spouses owning a life insurance product who were able to answer correctly to at least two out of the three SHIW questions which measure financial literacy, from the ones who were not. We consider them as having respectively "high" and "low" literacy. The Appendix shows that, on average, household heads give 
about two correct responses (the median is 2). As a consequence, low financial literacy in this section corresponds to giving less than the sample average correct answers. Financial literacy is measured in the SHIW survey through three questions. The questions assess the respondent's knowledge of the concepts of variable versus fixed interest-rate mortgage, inflation rate, portfolio risk and diversification. Two of the questions, regarding inflation and diversification, are similar to the questions formulated in the seminal paper by van Rooij et al. (2011), while the third is even more challenging than theirs, since in the van Rooij set-up it is sufficient to be aware of the difference between simple and compound interest rate to answer all questions correctly, while in the SHIW case a more subtle difference, between fixed versus variable interest rate, qualifies the respondent as 100\% financially literate. Given the importance that financial literacy will play later, Descriptive 1 separates the percentage of household heads and spouses owning a life insurance product who were able to answer correctly to at least two out of the three SHIW questions which measure financial literacy, from the ones who were not. We consider them as having respectively "high" and "low" literacy. The Appendix shows that, on average, household heads give about two correct responses (the median is 2). As a consequence, low financial literacy in this section corresponds to giving less than the sample average correct answers.

The table Descriptive 1 indicates that independently of gender, insurance coverage more than doubles for more financial knowledgeable households. Among those with low financial literacy, only about 3.8\% owns a life insurance, while among the financially literate respondents around $7.8 \%$ are insured. This already suggests that financial literacy is a driving factor of insurance demand. Furthermore, in the whole sample there is a substantial gender gap, and this is true at all levels of financial education. While $4.4 \%$ of the low-financially literate men own insurance, the percentage goes down to $3.2 \%$ for women with the same level of financial knowledge. The same happens for highly literate household heads and spouse: $9.5 \%$ of them buy insurance if men, only $5.9 \%$ if women. Since highly financially literate household give the average or higher than average answer, we can consider the column "high" of the table as quite representative of the sample: this explains why the last column, which includes the whole sample, is close to the "high" one.

\section{Descriptive 1: Percentage of insured individuals in the sample}

\section{Financial literacy (at least 2 out of 3 ) $\quad$ Total (\%)}

\begin{tabular}{lccc}
\hline Sex & low & high & \\
Male & 4.4 & 9.5 & 8.25 \\
Female & 3.2 & 5.9 & 5.2 \\
Total & 3.8 & 7.8 & 6.8 \\
\hline
\end{tabular}

Source: SHIW 2010 


\section{Empirical Analysis}

After the description of the data, let us investigate the determinants of life insurance demand, starting from participation (section 4.1) and then examining the amount of premiums paid, given participation (4.2). In Section 4.3 we explore robustness with respect to the inclusion of other non-compulsory annuities, i.e. private pension plans.

\subsection{Estimation results on life insurance participation}

We start our analysis by looking at the probability of owning a life insurance product. Results are presented in Table 2, which contains the marginal effects on that probability of increasing the regressors. A detailed description of them is in the Appendix.

We initially estimate the probability using a linear regression model and exploiting data available from the 2010 SHIW $^{8}$. This is the content of Columns 1 to 3 . All specifications include the traditional determinants of insurance demand such as gender, age, marital status, education, working situation, geographical variables, household composition, income, wealth, risk aversion. In addition to these variables, Column 1 includes financial literacy, while Column 2 takes into account the potential endogeneity of financial literacy by instrumenting it with two dummy variables indicating whether the mother or father of the respondent were managers, entrepreneurs or self-employed (when they had the same age of the respondents). Column 3 approximates financial inclusion with stock holding. In order to check the robustness of our results, we use the 2012 and 2010 wave to estimate a time and individual fixed effects model using the same regressors of the OLS estimation. ${ }^{9} 10$ We estimate the model using the whole sample as well as keeping males and females separated (Column 4-6). We focus mainly on the FE estimates, because they are the most robust.

Among the traditional determinants of life insurance demand, being a female, which is evidently taken into consideration when fixed effects are not present, lowers the demand for insurance, by $2 \%$ on average. Age is another significant variable, in all OLS specifications. The demand for life insurance is concave in age, as expected from its savings nature, with a peak at around $48^{11}$. In most specifications, the age of the spouse instead is not significant. The fact that age of the spouse if not a relevant determinant

8 We did not run the same regressions for 2012 since financial literacy had not been asked in the 2012 SHIW.

9 Given that financial literacy has not been measured in 2012, we have been able to estimate this FE model only by including stock holding. Financial literacy was measured in the 2008 survey as well, but the different questions about life insurance make it impossible to compare results across years. Indeed, in 2010 and 2012 individuals were asked if they owned a life insurance, and subsequently they were asked separately if the contract included a life and/or death clause. On the other hand, in 2008 the follow-up question asked about the death clause but not the life one. Therefore, since there are also mixed insurances which includes both life and death clauses, we cannot derive the total number of life insurances In other words, we can derive exactly how many pure life and death insurances were subscribed, but we cannot evaluate the number of mixed life insurances. As a consequence, we cannot even derive the premium paid for such insurances.

10 Since we use only two waves in these specifications, the individual FE is equivalent to a First-Difference estimator. Furthermore, adding both time dummies would lead to perfect collinearity, so only the indicator variable for 2010 has been included as a regressor.

${ }^{11} 0.0097 * 1000 /(0.1000 * 2)$ since age ${ }^{\wedge}$ is divided by 1000 . 
may suggest that the decision of buying a life insurance is done at the individual level rather than the family one ${ }^{12}$.

In the FE version, individuals who live together but are not legally married are more likely to have a life insurance. The same happens for married individuals, with the exception of males. Education is an important determinant in the OLS estimation, while is not significant any more once we look at the FE version. It is likely that the low significance level is due to the low variability in the sample because we have not included individuals younger than 25 .

We expect individuals who do not participate in the labor market and who are not retired yet to be more likely to have life insurance, because they need to protect themselves against the risk of not having enough income once old. Indeed, this is what we observe for males (Column 5). However, the coefficient of "inactive" is negative and significant for women. This is a particularly worrying result, especially if we take into account that women participate less in the labor force and are therefore at risk of underannuitization. Note that here we do not distinguish between households in which a man has the highest income from households in which the highest income comes from a woman. We do that because in both cases there would be a substantial amount of services, mainly care and housekeeping, which are non-monetized and not captured in the survey, and are very often provided by women. Our estimates say that, being the welfare of the household due to man or women, both in monetized and monetized terms, female individuals, all others equal, are asking for less insurance than men. In addition to this, the interaction between being a woman and being inactive is not significant, with the exception of the FE case.

Consistently with intuition and with the findings of Luciano, Outreville and Rossi (2015), we expect that being self-employed raises the probability of buying life insurance. While the OLS estimator is significant, we cannot reject the null that the FE estimator is zero. However, in the latter we are controlling for time invariant factors, such as risk aversion and entrepreneurial risk, which are likely to be related to the employment status.

Similarly, once we control for income and working status, we expect more individuals willing to subscribe to life insurance among the new generations, given the recent pension reforms and the precarious working conditions of these generations. Nevertheless, the number of working years does not significantly affects insurance demand, so it does not seem that young people protect themselves against income volatility later in life by insuring themselves, even keeping all the other determinants fixed.

\footnotetext{
${ }^{12}$ If the respondent did not have a spouse, the age of the spouse is set to zero. We have also tried to impute the average spouse in each wave if the respondent did not have a spouse: the results did not change substantially. Table available upon request
} 
The magnitude of the city where the household lives cannot be rejected to be null: in this sense, there does not seem to be a price effect, due to higher price levels in big cities, which was expected to lower insurance demand. In some isolated cases there is a negative effect of living either in the North or in the Center, with respect to the islands, which could reflect the just mentioned price effect.

Household composition does not seem to affect the participation to the insurance market, be it measured by the number of household members below, above 25 or offspring outside the household.

As predicted by most of the theoretical literature and confirmed in previous empirical literature, the logarithm of income has a positive effect on the demand for life insurance. ${ }^{13}$ This points to the nature of life insurance as a form of savings, and comes as no surprise. Nevertheless, the coefficient is no longer significant when the sample includes only women.

Individual income over wealth instead cannot be proved to be significant. Faced with concentration of income on one individual, households should rationally react by buying more insurance, so as to protect their permanent income. Despite this consideration, the coefficient does not differ significantly from zero, which may be again a worrying result for the member of the couple who earn less, i.e. typically the woman. The same happens with the ratio of the respondent's income over the total income of the family.

Risk aversion - which in the SHIW dataset is measured by the risk attitude of the financial decision maker in the household rather than at an individual level - cannot be proven to be significant in the OLS case, it has a positive effect when we go to FE, although it is not significant when only men are considered. However, we should remember that self-assessed risk aversion, as in the SHIW dataset, is usually not very reliable. We will have a confirmation of that for the current survey once we consider the rest of the household asset allocation, namely having stocks or a house. An individual who states not to be risk averse but diversifies is indeed quite contradictory in his statement.

Once we look at our regressors of interest, i.e. those used as proxies of financial inclusion, we can notice that home ownership increases the probability of having a life insurance. Despite this, its coefficient in the FE estimation is not statistically significant, probably because of the low variability of this regressor over time. The result for stock participation is more interesting: holding stock has a positive and significant coefficient both for the whole sample and for men alone, but not for women. When households participate to the financial markets, they do it across asset classes. On average, holding stocks increases by 5 percentage points the likelihood of having insurance, while this increase amounts to 8 percentage points for men. We attribute the evidence that holding stock does not matter for women to the fact that women are not the financial decision maker in most of the cases - and the questions about saving allocation are

\footnotetext{
${ }^{13}$ We include income in the regressions in $\log$ form since we expect the relationship to be exponential, i.e. linear in log.
} 
available at the family level only - thus holding a stock in the family is not necessarily reflecting a female decision.

Last but not least, our estimates allow us to claim that financial literacy is a key determinant of life insurance demand: as the descriptive statistics anticipated, literacy matters, in that both the estimates in the OLS and IV regressions are positive and significant. Improving financial literacy scores increases up to 45 percentage points the likelihood of having insurance ${ }^{14-15-16}$, while whether the family owns a stock increases the likelihood by almost 4 percentage points in the OLS regression. It is a fact that people who are financially literate do participate more to the stock market, hence, showing a better balanced portfolio (van Rooi et al. 2011). This is the case, also, of life insurance market participation.

\subsection{Estimation results on life insurance premiums}

This section studies the correlation of premiums paid with the explanatory variables introduced above. Instead of focusing simply on participation, we look at the amount of income or wealth devoted to insurance protection. We use a Tobit model to allow for the zero values of the dependent variable for those who do not have any insurance contract. The results are presented in Table 3. As in Table 2, Column 1 includes financial literacy among the regressors, Column 2 accounts for the endogeneity of financial literacy by fitting an IV Tobit model ${ }^{17}$, Column 3 one uses stock holding as a proxy for financial inclusion.

First of all, the coefficient of women is negative, statistically significant and it has an ample magnitude in all specifications. This confirms the scarce importance given to annuitization and consumption smoothing by the female head or spouse, even when they participate, either because she does not contribute to the household income, or because her role is not monetized. It may thus signal that women undervalue the opportunity cost associated to their role in the household.

Second, as it already happened with participation, premiums paid are concave in the age of the household head, while the age of the household's spouse does not seem to play a relevant role.

\footnotetext{
14 The OLS estimate is significantly lower than the IV one. This downward bias of the OLS coefficient may be due, among other things, to measurement errors.

${ }^{15}$ Since we have two instruments (mother and father working conditions), we can test the exogeneity of these instruments through a Sargan-Hansen J test. The Hansen p-value reported at the end of Table 2 is very high, thus we are far from rejecting the null, which means that we can be confident in the exogeneity of our instruments.

16 As usual with the IV strategy, we may be concerned about the weakness of our instruments. In order to dissipate any doubt, we estimated the same model using a LIML estimation, which is less biased than the 2SLS in case of week instruments. Furthermore, we picked our strongest instrument, i.e. father managerial ability, and we estimated a simple IV model, which is median-unbiased and therefore not subject to the same critiques. The estimated coefficients of financial literacy are still between 0.44 and 0.45 , thus supporting our results. Finally, we have also estimated a GMM model, which is more efficient: the coefficient of financial literacy is still significant at $1 \%$ level. Tables available upon request.

17 The Stata command ivtobit provides a Wald test for the exogeneity of financial literacy: since the test statistic is significant, we can reject the null hypothesis of no endogeneity. Thus, the IV strategy is appropriate here.
} 
Living together is insignificant, while being married is relevant only in the IV specifications.

Holding higher education (high school and more) was significant in the OLS estimation of life insurance demand but not in the IV and FE ones. Similarly, both secondary and tertiary educations are positive and significant in the Tobit specifications, even if they become insignificant in the IV Tobit one. This suggests that general education gives a sense of the amount of coverage one needs, once he decided to enter the insurance market, more than affecting the decision to insure or not. In most cases, it is positively associated with the sensitivity of the insurance demand.

Contrary to what we found above for participation, the intensity of life insurance demand does not depend on the employment condition. Indeed, both "inactive" and its interaction with the female indicator have insignificant coefficients. Nevertheless, selfemployed workers tend to pay higher premiums, in the same way as they tended to participate more ${ }^{18}$. The number of working years is still not relevant.

Geographical variables, in the sense of amplitude of the city one lives in, are still not significant. Living in the North or Center has again a negative effect. So, geographical variables play roughly the same role they had for participation.

A similar phenomenon occurs for the age mix of the dependents and the presence of offspring outside the house, which again do not affect the level of premiums.

Income has a positive and significant effect in all specifications except when financial literacy is instrumented. On the other hand, income over wealth and individual income over household income are never significant.

Stock market participation has positive and significant coefficients with a high magnitude. Even home ownership has a substantial impact, although it disappears in the IV specifications.

Risk aversion is not significant in explaining the amount spent. Again, we would impute this to the fact that risk-aversion is self-assessed, since other implicit indicators of risk aversion in the survey, i.e. diversification via home ownership and stock holding, do appear significant.

Home ownership has a substantial impact, although it disappears in the IV specifications. Stock market participation has positive and significant coefficients with a high magnitude.

\footnotetext{
18 This holds true in all specifications except when financial literacy is instruments. We can explain this change by noticing that the excluded instruments, i.e. mother and father managerial experiences are highly correlated not only with financial literacy, but also with self-employment.
} 
Once taking into account endogeneity, financial literacy seems to be the driving force among the human capital variables. As for market participation, our new regressors turn out to be extremely important in determining the intensity of the life insurance demand. Home ownership, stock market participation and financial literacy, either combined or in isolation, appear as significant and give a high contribution to the explanation of premiums. This confirms the role of financial market inclusion, as well as the understanding of risky market values and payoffs, in explaining the amount of hedging through insurance. People who are included in the financial market participate more and spend more than their peers, all others equal. Alternatively, risk aversion is better approximated by observed diversification through the stock than by self-declarations. ${ }^{19}$

\subsection{Estimation results on life insurance and pension funds}

As a robustness check, we have used the same model as in Section 4.1 but we have considered as dependent variable an indicator equal to one if the respondent owned a life insurance or a pension fund. This has allowed us to extend the analysis using the 2004 and 2006 waves, where - opposite to what happens with the other waves insurance and pension participation were not separated. Results are reported in Table 4, where, as before, the first column includes all respondents, while the next two are divided by gender.

We have also added as control a variable indicating whether the respondent's severance payment (TFR) had been allocated to a pension fund. This has been necessary in order to take into account the reform implement in 2007 where the employee could decide to leave his or her severance package to the employer, or to invest it with a pension fund. The default option was the pension fund, so the ones who answered "don't know" to the question whether they had a fund or not were counted as having it. Since the reform started in 2007, the indicator variable takes always value zero in the 2004 and 2006 waves. This may be considered a strong imputation, so we checked our results by including an addition column where only 2010 and 2012 were used. Results do not change substantially. This last column is also useful also to compare the coefficients between Table 2 and 4.

Home-ownership has now negative and significant coefficients. This result - apparently difficult to reconcile with the previous ones - is not contradictory: here we are explaining participation, and we can think of having real estate as a factor which fosters insurance,

\footnotetext{
${ }^{19}$ At this point, we may worry that the restrictions imposed by the Tobit model are too stringent: we are assuming that the same variables explain participation to the life insurance market and the premium amount. Furthermore, the coefficients have to have the same sign both when explaining the probability of a nonzero observation and the level of a positive one. In addition to this, the Tobit model - since it is built to take into account the censoring of the latent variable - predicts not only a cluster of zeros, but also some relevant mass around zero. We do not believe that these assumptions are too strong in this setting: there are no potential variables which would affect participation but not demand intensity, not the sign of the regressors is expected to differ, and there is some relevant mass around zero. Even if the latter were not true, the coefficient would be attenuated, so our results would still be valid. Nevertheless, in order to check the robustness of our estimates, we have estimated a Heckman (Tobit II) model where the first step is a Probit model for computing the probability of owning a life insurance ( $0-1$ variable), and the second step has the premium amount as dependent variable, so people without insurance have missing values for premium amount. In the second stage, the coefficient of the Mill's ratio is not statistically different from zero, thus we can rule out the sample selection issue. Results are available upon request.
} 
because it signals proximity to the financial market, while it depresses the quest for additional pensions.

The main - reassuring - result is that the effect of holding stock is again positive and significant in all specifications. This supports the conclusions drawn in the previous sections: financial inclusion is a pivotal determinant of life insurance demand. 


\section{Concluding Remarks}

Our study on life insurance determinants points at a pivotal driver, which stands as a natural candidate to explain most of the intensity of insurance subscription: financial inclusion - as measured by financial literacy or stock and home holding. Individuals with higher participation to the financial market have knowledge of insurance potentials and thus they subscribe a life insurance product.

The conclusion is thus that fostering financial inclusion, which stands as the main factor in shaping the demand for insurance, both participation and invested amounts would generate huge spillovers by increasing the number of people covered by life insurances. Fostering education in a targeted way, by improving financial education, would work at best as a device to foster insurance participation and, as a spillover effect, would reduce the vulnerability of those people who are at risk of under-annuitization or of running out of wealth in the old age $e^{20}$.

This holds in particular for women, who, as shown above, demand less insurance than men and are often out of the labor market. They would benefit most from a broader financial inclusion. Indeed, in our sample in 2012 almost 37\% of women (24\% men) were not participating into the labor market ${ }^{21}$. If we exclude retired individuals, $20 \%$ women were inactive. Among this group, 19\% were not married. Furthermore, taking into account the divorce rates computed by ISTAT $^{22}$, almost $60 \%$ among inactive women in 2012 should be considered vulnerable since they were not married or they were likely to getting divorced in the future. Therefore, $12 \%$ of Italian women is at risk of not being able to sustain themselves once retired because they did not pay any pension contribution and in many cases do not save enough (nor do their husbands on their account). Life insurance is an important tool to protect these individuals, therefore we hope that this paper will help policy-makers in designing appropriate actions to increase annuitization when appropriate.

\footnotetext{
${ }^{20}$ We are aware that, as documented in Ania (2015), the percentage of life insurances converted into annuities is very small. However, what we are claiming here is that this financial tool would be extremely useful to protect against the risk of under-annuitization. Therefore, the key aspect is just the possibility embedded in the life insurance to convert the accumulated wealth into a constant flow of income which can raise living standards during retirement age, not whether life insurances are currently use for such purpose.

21 This is in line with the official statistics of 39.7\%. Source: https://research.stlouisfed.org/fred2/series/ITALFPWNA. Are considered as not employed individuals who are unemployed, looking for their first job, housewives, retired, students, volunteers and wealthy. The questionnaire also includes children younger than 6 , who are not present in our sample since we selected individuals aged between 25 and 65 .

22 Source: http://www.istat.it/it/archivio/126552
} 


\section{References}

Ania, (2014), L'assicurazione Italiana 2013-14.

Ania (2015), Indagine campionaria sul ricorso alla rendita vitalizia: Esercizi 2011-2013.

Beck T., and Webb, I., 2003, Economic, demographic and institutional determinants of life insurance consumption across countries, World Bank Econ Rev, 17(1): 51-88.

Bernheim, B. D., 1991, How Strong Are Bequest Motives? Evidence Based on Estimates of the Demand for Life Insurance and Annuities, Journal of Political Economy, 99: 899-927.

Bernheim, B. D., Forni, L., Gokhale, J., and Kotlikoff. L., 2003, The mismatch between life insurance holdings and financial vulnerabilities: evidence from the Health and Retirement Study, American Economic Review, 93 (1): 354-365.

Brown J., 2008, Financial Education and Annuities, OECD Journal: General Papers, OECD Publishing, 2008 (3), pages 173 ff.

Brown J., Kling, J. R., Mullainathan, S. and Wrobel, M.V., 2008, Why Don't People Insure Late-Life Consumption? A Framing Explanation of the Under-Annuitization Puzzle, American Economic Review, American Economic Association, 98(2): 304-09.

Brown, J. R., Mitchell, O. s:, and Poterba, J.M., 2001, .The Role of Real Annuities and Indexed Bonds in an Individual Accounts Retirement Program, in John Y. Campbell and Martin Feldstein (eds.): Risk Aspects of Investment-Based Social Security Reform, Chicago: the University of Chicago Press, 321-370.

Calcagno R. and C. Urzì Brancati, (2014), Do more financially literate households invest less in housing? in Economics Bulletin, Vol. 34 No. 1 pp. 430-445

Davidoff, T, Brown, J.R., and Diamond P.A. , 2005, Annuities and Individual Welfare, American Economic Review, 95(5): 1573-1590.

De Nardi, M., 2004, Wealth Inequality and Intergenerational Links, Review of Economic Studies, 71: 743-768.

Dushi, I. and Webb, A., 2004, .Household Annuitization Decisions: Simulations and Empirical Analysis,.Journal of Pension Economics and Finance, 3 (2), 109-143.

Guiso L. and E. Viviano, 2013, How much can financial literacy help? CEPR Discussion Paper No. DP9693

Hurd, M. D., 1987, Savings of the Elderly and Desired Bequests, American Economic Review, 77 (3): 298-312.

Inkmann, J., Lopes, P. and Michaelides, A., 2011. How Deep Is the Annuity Market Participation Puzzle?, Review of Financial Studies, 24(1): 279-319. 
Jappelli, T. and Padula, M. (2013). Investment in financial literacy and saving decisions. Journal of Banking \& Finance, 37(8):2779-2792.

Jappelli T. and Pistaferri, L., 2002, Tax incentives and the demand for life insurance: evidence from Italy, Journal of Public Economics, 87 (7-8,): 1779-1799.

Kopczuk, W. and Lupton, J., 2007, To Leave or not to Leave: the Distribution of Bequest Motives, Review of Economic Studies, 74 (1): 207-235.

Lewis, F.D. 1989, Dependents and the Demand for Life Insurance, American Economic Review, 79: 452-466.

Li, D., Moshirian, F., Nguyen, P. and Wee, T., 2007. The demand for life insurance in OECD countries, Journal of Risk and Insurance, 74(3): 637-652.

Lin, Y. and Grace, M. F., 2007, Household Life Cycle Protection: Life Insurance Holdings, Financial Vulnerability, and Portfolio Implications, The Journal of Risk and Insurance, 74: 141-173.

Lusardi, A., and Mitchell, O.S., 2007, Baby boomer retirement security: The roles of planning, financial literacy, and housing wealth. Joumal of Monetary Economics, 54: 205-224.

Lusardi, A., and Mitchell, O.S. 2011, Financial literacy and planning: Implications for retirement wellbeing. In O. S. Mitchell \& A. Lusardi (Eds.), Financial literacy: Implications for retirement security and the financial marketplace (pp. 17-39). Oxford, UK: Oxford University Press.

Millo G. and Carmeci G., 2011, Non-life insurance consumption in Italy: a sub-regional panel data analysis, Journal of Geographical Systems, 13(3): 273-298.

Outreville, J. F., 1996, Life Insurance Markets in Developing Countries, Journal of Risk and Insurance, 63: 263-278.

Outreville, J.F., 2014, The relationship between relative risk aversion and the level of education: a survey and implications for the demand for life insurance, Journal of Economic Surveys, forthcoming, available on line.

Sen, S., 2008, Are Life Insurance Demand Determinants valid for Selected Asian Economies and India? Madras School of Economics Working Paper; No. 36/2008

van Rooij, M., Lusardi, A., and Alessie, R., 2011, Financial literacy and stock market participation, Journal of Financial Economics, 101(2): 449-472

Yaari M., 1965, Uncertain Lifetime, Life Insurance, and the Theory of the Consumer, Review of Economic Studies, 32 (2): 137-50. 
Appendix

Descriptive Statistics (2010)

\begin{tabular}{lccccc} 
Variable & Obs & Mean & Std.Dev. & Min & Max \\
\hline & & & & & \\
Life insurance & 7,580 & 0.067942 & 0.251663 & 0 & 1 \\
Life insurance or Pension fund & 7,580 & 0.203298 & 0.402479 & 0 & 1 \\
Premium amount (Tobit) & 7,580 & 113.6248 & 695.9824 & 0 & 31021.7 \\
Premium amount (Heckman) & 515 & 1672.381 & 2128.5 & 106.2387 & 31021.7 \\
Female & 7,580 & 0.478892 & 0.499587 & 0 & 1 \\
Age hh Head & 7,580 & 49.61201 & 10.27054 & 21 & 84 \\
Age hh Head^2 & 7,580 & 2.566821 & 1.007043 & 0.441 & 7.056 \\
Age hh Head spouse & 7,580 & 39.68562 & 21.18634 & 0 & 81 \\
Age hh Head spouse`2 & 7,580 & 2.02375 & 1.309731 & 0 & 6.561 \\
Living together & 7,580 & 0.031794 & 0.175463 & 0 & 1 \\
Married & 7,580 & 0.787203 & 0.409312 & 0 & 1 \\
High School & 7,580 & 0.325066 & 0.46843 & 0 & 1 \\
Tertiary education & 7,580 & 0.15 & 0.357095 & 0 & 1 \\
Inactive & 7,580 & 0.112797 & 0.316365 & 0 & 1 \\
Female*Inactive & 7,580 & 0.088786 & 0.284454 & 0 & 1 \\
Self-Employed & 7,580 & 0.135488 & 0.342267 & 0 & 1 \\
\# working years & $\mathbf{6 , 7 9 3}$ & 23.06521 & 11.07312 & 1 & 49 \\
Medium city & 7,580 & 0.185092 & 0.388398 & 0 & 1 \\
Large city & 7,580 & 0.457124 & 0.498191 & 0 & 1 \\
Mega city & 7,580 & 0.094063 & 0.291936 & 0 & 1 \\
North Italy & 7,580 & 0.450528 & 0.497579 & 0 & 1 \\
Centre Italy & 7,580 & 0.214644 & 0.410602 & 0 & 1 \\
\# hh members <=25 & 7,580 & 0.943668 & 0.996428 & 0 & 6 \\
\# hh members > 25 & 7,580 & 0.267019 & 0.578175 & 0 & 5 \\
Offspring outside hh & 7,580 & 0.288391 & 0.453044 & 0 & 1 \\
Log(Ind Income) & 7,580 & 9.76088 & 0.853612 & 3.198519 & 11.68716 \\
IndIncome/Wealth & 7,580 & 199.7552 & 1643.259 & -94.1042 & 26559.67 \\
IndIncome/hhIncome & 7,580 & 0.60405 & 0.294735 & 0.000895 & 4.378581 \\
Holding stocks & 7,580 & 0.082454 & 0.275073 & 0 & 1 \\
Home-owner & 7,580 & 0.711214 & 0.453228 & 0 & 1 \\
Risk Averse & 7,580 & 0.418338 & 0.493319 & 0 & 1 \\
Financial literacy & 7,580 & 2.064644 & 0.939405 & 0 & 3 \\
& & & & & \\
& & & &
\end{tabular}




\section{Variable description}

This appendix contains the detailed description of all the variables used in the regression models. All income and wealth indicators, as well as premium amounts, have been adjusted for inflation ${ }^{23}$.

Life insurance is a dummy dependent variable which takes value one if the respondent owned a life insurance. Note that this includes also mixed policies, but not pure death insurances ${ }^{24}$.

Life insurance or Pension fund is a dummy dependent variable which takes value one if the respondent owned a life insurance or a private pension fund. Severance pays transfers to private pension plans are also included.

Premium amount is the amount paid for the individual insurance by the interviewed household in the year of the survey. In the Tobit model, this dependent variable includes premiums both for life and mixed insurances, while it takes value zero if they individual did not own an insurance or if the insurance was a pure death one. On the other hand, in the Heckman model premium amount is missing for those uninsured or with a death insurance ${ }^{25}$.

In 2007 a reform had been introduced which, in absence of an explicit choice of the worker, allocated the severance payment to a pension fund (TFR to pension). In order to take into account the effect of such reform, we have added as regressor whether the respondent had decided to allocate his or her severance pay to a pension fund ${ }^{26}$. Given the default option, if the individual did not know, we had assumed that the money had been indeed dedicated to a pension plan. "No reply" was imputed as missing. Obviously, such variable takes always value zero in the two waves before the reform.

$\log ($ Individual Income) is the logarithm of the individual net, or disposable, income. This individual income includes labor income, capital gains, pension and other transfers. This variable takes value zero if the individual income was reported to be negative or missing. From the panel dataset, the observations in the upper and lower 0.5 percentile of the individual income distribution have been dropped.

\footnotetext{
23 Source: All-items HICP annual data from Eurostat

${ }^{24}$ Note that in 2010 and 2012 individuals were asked if they owned a life insurance, and subsequently they were asked separately if the contract included a life and/or death clause. As explained before, in 2008 the follow-up question asked about the death clause but not the life one, so it is not comparable and this wave has not been included in the analysis. In 2004 and 2002 there was one question dedicated to death insurance, while life insurance had been measured together with private pension funds, so it has been possible to include these waves only in the last empirical section. Finally, in 2002 individuals were asked if they owned a life insurance, but there is no follow-up question, thus this wave has been excluded because it is impossible to distinguish between life and death insurance.

25 This dependent variable has still some zeros because few respondents (below 5\% of the insured) had a life insurance but they did not pay any premium in the year of the interview.

${ }^{26}$ Indeed, in the 2012 and 2010 questionnaire, individuals were explicitly asked to count as private pension policies all the severance pays allocated to a pension fund.
} 
Individual income/Household income is the ratio of individual income over the total income of the household, which provides a measure of how important the contribution of the individual is to the total disposable resources of the family.

Individual income/Wealth is the ratio of the net individual income and net wealth. Net wealth includes real assets, financial assets and debts. This ratio has been set equal to individual income if wealth was reported to be zero.

Female is a dummy variable which is equal to one if the respondent is a woman.

Age hh Head is the age of the household head, while Age hh Head spouse is the age of the household head's spouse. If the household head does not have a partner, the latter is set to zero. In order to capture any concavity, we have also included among the regressors the squared of both variables (divided by 1000). Note that we have considered only observation whose age was between 25 and 65. However, since some individuals have younger partners, some of these variables may actually take values lower than 25 (see the summary statistics above).

Married is an indicator variable which takes value one if the respondent declares that he/she is married.

Living together is an indicator variable which takes value one if the respondent declares that he/she is single/divorce/widow but somebody in the household declared to be the spouse or the cohabitee.

High school is an indicator variable which takes value one if the respondent has a high school diploma

Tertiary education is an indicator variable which takes value one if the respondent has at least a bachelor degree.

Offspring outside $h b$ is an indicator variable which takes value one if the respondent or his/her partner has a son or a daughter alive and living not in the same household.

North/Centre/South is an indicator variable which takes value one if the respondent lives in North Italy/Centre Italy/South Italy and Islands (the latter being the baseline). We have included these geographical dummies because in Italy there are a lot of cultural differences among North, Centre and South, on top of income and job market status.

Small city is an indicator variable which takes value one if the respondent lives in a city with population $0-20,000$. This is the baseline.

Medium city is an indicator variable which takes value one if the respondent lives in a city with population $20,000-40,000$

Large city is an indicator variable which takes value one if the respondent lives in a city with population $40,000-500,000$ 
Mega city is an indicator variable which takes value one if the respondent lives in a city with population over 500,000 .

Self-employed is an indicator variable which takes value one if the respondent was working as entrepreneur, freelancers, self-employed, artisan, owner or member of a family business, and similar. We did not include among them the uncharacteristic workers since their precarious working conditions are very different from the other categories.

Inactive is an indicator variable which takes value one if the respondent did not participate in the labor market (such as students, unemployed people, and housewives) and he/she was not retired. We have also added the interaction Female*Inactive to capture a potential gender heterogeneity.

Risk averse is also a dummy variable that takes the value of one if the respondent has given the lowest degree of appeal to risky portfolio ${ }^{27}$.

In order to control for the number of components and their different role in the family we include a set of a variables counting the household members within a certain age range. We count the Number of Components below 25 years and the Number of Components above 25 years. These numbers do not include the household head and the spouse since we already accounted for them by adding their ages as regressors.

Home-owner is an indicator variable which takes value one if the respondent owned the house where the household used to live.

Holding stock is an indicator variable which takes value one if the respondent owned Italian or foreign stock, mutual funds and shares.

Number of working years count the years in which the worker of his/her employer has paid pension contributions. Years required for obtaining a bachelor have been included if the respondent had paid the required contribution.

Financial literacy counts the number of correct answers that the respondent gave to the three questions concerning financial education. The first question is about uncertain and the difference between fixed and variable interest rate. The second question concerns inflation, real and nominal interest rates. The third question measures the understanding of risk and diversification strategies. In 2010, around $16.9 \%$ individuals in the sample made two mistakes, $35.6 \%$ answered two questions correctly, while $39.5 \%$ answered all questions correctly.

\footnotetext{
27 The question RISKFIN used is the following: "In managing your financial investments, would you say you have a preference for investments that offer:

1. a very high returns, but with a high risk of losing part of the capital

2. a good return, but also a fair degree of protection for the invested capital

3. a fair return, with a good degree of protection for the invested capital

4. low returns, with no risk of losing the invested capital."
} 
Father and mother managers: in order to take into consideration potential endogeneity of financial literacy, we have instrumented the financial literacy score using as instruments two dummy variable taking the value of one if the respondent's father or mother had high managerial job at the age of the respondent ${ }^{28}$. The rational of the instrument relies on the fact that having a parent with higher education or managerial job increases the likelihood of having a higher cognitive ability and financial knowledge (Calcagno and Urzì, 2014)

\footnotetext{
${ }^{28}$ The main respondent is asked "what was the occupation of your mother and father at your age?". We consider managers, freelancers and entrepreneurs as managerial occupations so as to build up the instruments.
} 
Table 2: Life Insurance (D)

\begin{tabular}{|c|c|c|c|c|c|c|}
\hline & $\begin{array}{c}(1) \\
\text { OLS - FinLit }\end{array}$ & $\begin{array}{c}\text { (2) } \\
\text { IV - FinLit }\end{array}$ & $\begin{array}{c}(3) \\
\text { OLS - Stock }\end{array}$ & $\begin{array}{c}\text { (4) } \\
\text { FE - All }\end{array}$ & $\begin{array}{c}\text { (5) } \\
\text { FE - Male }\end{array}$ & $\begin{array}{c}(6) \\
\text { FE - Female }\end{array}$ \\
\hline Female & $\begin{array}{l}-0.0180^{* *} \\
(0.0071)\end{array}$ & $\begin{array}{l}-0.0214^{*} \\
(0.0114)\end{array}$ & $\begin{array}{c}-0.0179^{* *} \\
(0.0071)\end{array}$ & & & \\
\hline Age hh Head & $\begin{array}{l}0.0097^{* * *} \\
(0.0025)\end{array}$ & $\begin{array}{l}0.0122^{* *} \\
(0.0057)\end{array}$ & $\begin{array}{l}0.0095^{* * *} \\
(0.0025)\end{array}$ & $\begin{array}{l}-0.0115 \\
(0.0160)\end{array}$ & $\begin{array}{c}0.0171 \\
(0.0284)\end{array}$ & $\begin{array}{l}-0.0259 \\
(0.0172)\end{array}$ \\
\hline Age hh $\mathrm{Head}^{\wedge} 2$ & $\begin{array}{c}-0.1000^{* * *} \\
(0.0250)\end{array}$ & $\begin{array}{l}-0.1309^{* *} \\
(0.0580)\end{array}$ & $\begin{array}{c}-0.0982^{* * *} \\
(0.0250)\end{array}$ & $\begin{array}{c}0.0474 \\
(0.1211)\end{array}$ & $\begin{array}{l}-0.2334 \\
(0.2084)\end{array}$ & $\begin{array}{c}0.1830 \\
(0.1360)\end{array}$ \\
\hline Age hh Head spouse & $\begin{array}{l}-0.0010 \\
(0.0015)\end{array}$ & $\begin{array}{c}-0.0094^{* *} \\
(0.0044)\end{array}$ & $\begin{array}{l}-0.0008 \\
(0.0015)\end{array}$ & $\begin{array}{l}-0.0011 \\
(0.0042)\end{array}$ & $\begin{array}{l}-0.0056 \\
(0.0075)\end{array}$ & $\begin{array}{l}-0.0006 \\
(0.0053)\end{array}$ \\
\hline Age hh Head spouse^2 & $\begin{array}{l}-0.0008 \\
(0.0172)\end{array}$ & $\begin{array}{c}0.1087^{*} \\
(0.0555)\end{array}$ & $\begin{array}{l}-0.0036 \\
(0.0172)\end{array}$ & $\begin{array}{l}-0.0174 \\
(0.0590)\end{array}$ & $\begin{array}{c}0.0797 \\
(0.1196)\end{array}$ & $\begin{array}{l}-0.0351 \\
(0.0729)\end{array}$ \\
\hline Living together & $\begin{array}{c}0.0088 \\
(0.0363)\end{array}$ & $\begin{array}{l}0.2025^{*} \\
(0.1063)\end{array}$ & $\begin{array}{c}0.0037 \\
(0.0363)\end{array}$ & $\begin{array}{l}0.2006^{* *} \\
(0.0859)\end{array}$ & $\begin{array}{l}0.2686^{*} \\
(0.1523)\end{array}$ & $\begin{array}{l}0.1485^{*} \\
(0.0870)\end{array}$ \\
\hline Married & $\begin{array}{c}0.0415 \\
(0.0341)\end{array}$ & $\begin{array}{l}0.1815^{* *} \\
(0.0838)\end{array}$ & $\begin{array}{c}0.0374 \\
(0.0340)\end{array}$ & $\begin{array}{l}0.1647^{* *} \\
(0.0733)\end{array}$ & $\begin{array}{c}0.1886 \\
(0.1415)\end{array}$ & $\begin{array}{l}0.1638^{*} \\
(0.0865)\end{array}$ \\
\hline High School & $\begin{array}{l}0.0194^{* * *} \\
(0.0073)\end{array}$ & $\begin{array}{l}-0.0488 \\
(0.0307)\end{array}$ & $\begin{array}{l}0.0192^{* * *} \\
(0.0073)\end{array}$ & $\begin{array}{c}0.0077 \\
(0.0382)\end{array}$ & $\begin{array}{l}-0.0564 \\
(0.0548)\end{array}$ & $\begin{array}{c}0.0488 \\
(0.0485)\end{array}$ \\
\hline Tertiary education & $\begin{array}{l}0.0429^{* * *} \\
(0.0113)\end{array}$ & $\begin{array}{l}-0.0347 \\
(0.0367)\end{array}$ & $\begin{array}{l}0.0418^{* * *} \\
(0.0114)\end{array}$ & $\begin{array}{c}0.0656 \\
(0.0931)\end{array}$ & $\begin{array}{c}0.0555 \\
(0.1573)\end{array}$ & $\begin{array}{c}0.0563 \\
(0.0508)\end{array}$ \\
\hline Inactive & $\begin{array}{c}0.0196 \\
(0.0204)\end{array}$ & $\begin{array}{l}-0.0812 \\
(0.0564)\end{array}$ & $\begin{array}{c}0.0195 \\
(0.0204)\end{array}$ & $\begin{array}{l}0.0820^{* * *} \\
(0.0308)\end{array}$ & $\begin{array}{l}0.0967^{* * *} \\
(0.0336)\end{array}$ & $\begin{array}{l}-0.0274^{*} \\
(0.0145)\end{array}$ \\
\hline Female*Inactive & $\begin{array}{l}-0.0037 \\
(0.0235)\end{array}$ & $\begin{array}{c}0.0730 \\
(0.0577)\end{array}$ & $\begin{array}{l}-0.0056 \\
(0.0235)\end{array}$ & $\begin{array}{c}-0.0962^{* * *} \\
(0.0344)\end{array}$ & & \\
\hline Self-Employed & $\begin{array}{l}0.0541^{* * *} \\
(0.0114)\end{array}$ & $\begin{array}{l}-0.0076 \\
(0.0300)\end{array}$ & $\begin{array}{l}0.0551^{* * *} \\
(0.0114)\end{array}$ & $\begin{array}{c}0.0327 \\
(0.0274)\end{array}$ & $\begin{array}{r}0.0487 \\
(0.0377)\end{array}$ & $\begin{array}{l}-0.0059 \\
(0.0371)\end{array}$ \\
\hline \# working years & $\begin{array}{l}-0.0000 \\
(0.0004)\end{array}$ & $\begin{array}{l}-0.0020^{*} \\
(0.0012)\end{array}$ & $\begin{array}{c}0.0000 \\
(0.0004)\end{array}$ & $\begin{array}{l}-0.0001 \\
(0.0011)\end{array}$ & $\begin{array}{l}-0.0005 \\
(0.0017)\end{array}$ & $\begin{array}{c}0.0005 \\
(0.0014)\end{array}$ \\
\hline Medium city & $\begin{array}{c}0.0086 \\
(0.0106)\end{array}$ & $\begin{array}{c}0.0302 \\
(0.0223)\end{array}$ & $\begin{array}{c}0.0071 \\
(0.0107)\end{array}$ & $\begin{array}{l}-0.0287 \\
(0.0386)\end{array}$ & $\begin{array}{l}-0.0621 \\
(0.0571)\end{array}$ & $\begin{array}{c}0.0262 \\
(0.0251)\end{array}$ \\
\hline Large city & $\begin{array}{l}-0.0054 \\
(0.0082)\end{array}$ & $\begin{array}{c}0.0240 \\
(0.0201)\end{array}$ & $\begin{array}{l}-0.0068 \\
(0.0082)\end{array}$ & $\begin{array}{l}-0.0652 \\
(0.0574)\end{array}$ & $\begin{array}{l}-0.1306 \\
(0.0850)\end{array}$ & $\begin{array}{c}0.0122 \\
(0.0272)\end{array}$ \\
\hline
\end{tabular}




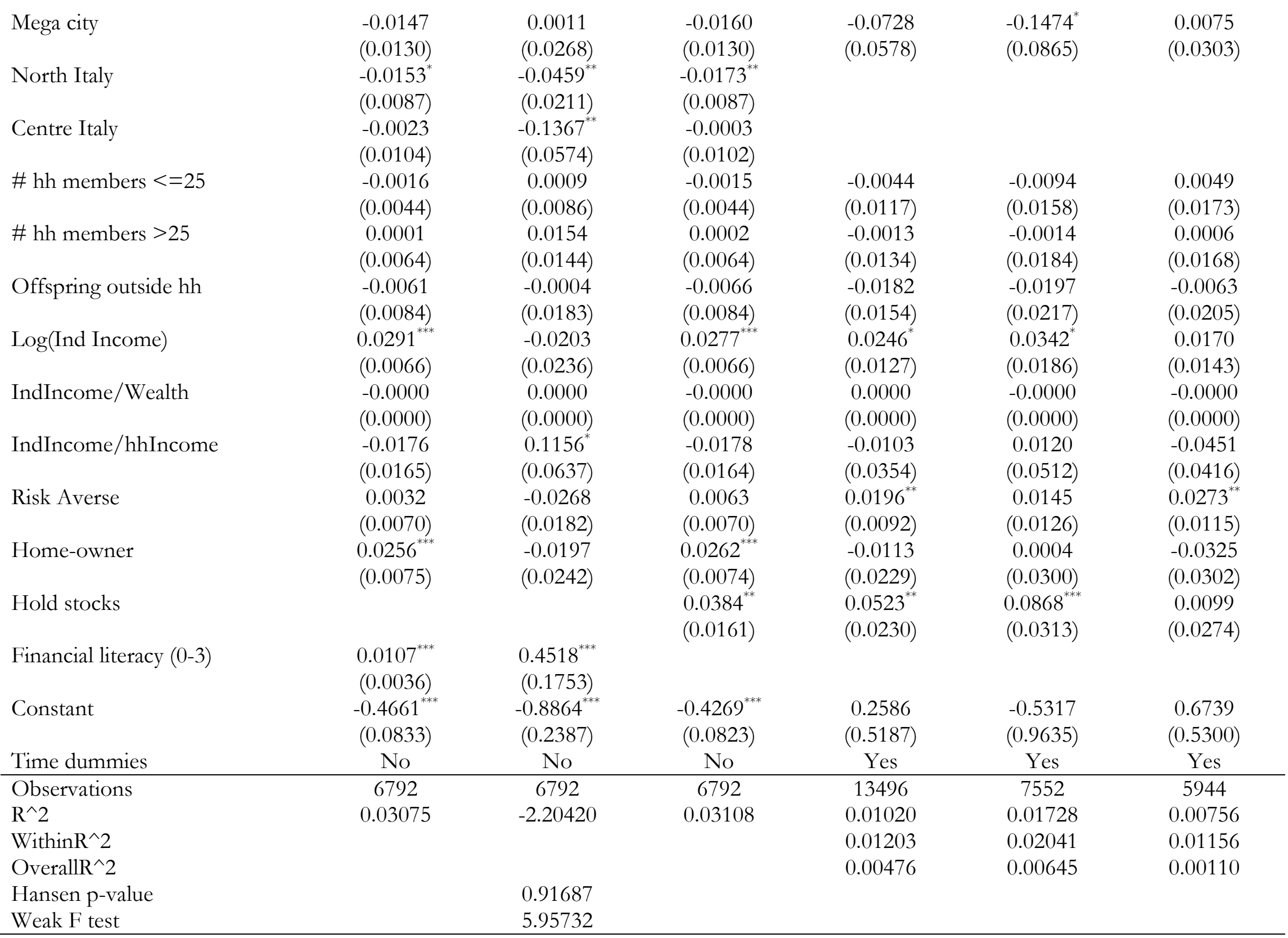


Standard errors in parentheses

Clustered SE at household level

Source: SHIW 2010-2012, individuals aged 25-65, household head and partner

Upper and lower 0.5 percentile of individual income dropped

Excluded instruments for financial literacy: father and mother manager, entrepreneur, self-employed

Note: age ${ }^{\wedge}$ has been divided by 1000

${ }^{*} p<0.10,{ }^{* *} p<0.05,{ }^{* * *} p<0.01$ 


\begin{tabular}{|c|c|c|c|}
\hline & $\begin{array}{c}\text { (1) } \\
\text { Tobit - FinLit }\end{array}$ & $\begin{array}{c}\text { (2) } \\
\text { IV Tobit - FinLit }\end{array}$ & $\begin{array}{c}(3) \\
\text { Tobit - Stock }\end{array}$ \\
\hline Female & $\begin{array}{c}-513.4^{* *} \\
(240.7)\end{array}$ & $\begin{array}{l}-598.1^{*} \\
(345.9)\end{array}$ & $\begin{array}{l}-522.4^{* *} \\
(242.2)\end{array}$ \\
\hline Age hh Head & $\begin{array}{l}420.1^{* * *} \\
(120.8)\end{array}$ & $\begin{array}{l}467.8^{* * *} \\
(138.1)\end{array}$ & $\begin{array}{l}406.9^{* * *} \\
(121.1)\end{array}$ \\
\hline Age hh Head^2 & $\begin{array}{l}-4472.5^{* * *} \\
(1279.4)\end{array}$ & $\begin{array}{l}-5051.3^{* * *} \\
(1433.2)\end{array}$ & $\begin{array}{l}-4342.3^{* * *} \\
(1282.3)\end{array}$ \\
\hline Age hh Head spouse & $\begin{array}{l}-13.1 \\
(45.8)\end{array}$ & $\begin{array}{l}-185.5^{* *} \\
(93.5)\end{array}$ & $\begin{array}{c}-6.3 \\
(45.9)\end{array}$ \\
\hline Age hh Head spouse 2 & $\begin{array}{l}-263.1 \\
(575.3)\end{array}$ & $\begin{array}{c}1958.2^{*} \\
(1185.2)\end{array}$ & $\begin{array}{l}-358.4 \\
(579.8)\end{array}$ \\
\hline Living together & $\begin{array}{c}-572.1 \\
(1144.3)\end{array}$ & $\begin{array}{l}3363.5 \\
(2260.6)\end{array}$ & $\begin{array}{c}-764.0 \\
(1148.1)\end{array}$ \\
\hline Married & $\begin{array}{l}901.0 \\
(959.9)\end{array}$ & $\begin{array}{l}3799.9^{* *} \\
(1797.9)\end{array}$ & $\begin{array}{l}776.0 \\
(954.6)\end{array}$ \\
\hline High School & $\begin{array}{l}641.8^{* * *} \\
(241.9)\end{array}$ & $\begin{array}{l}-780.5 \\
(637.5)\end{array}$ & $\begin{array}{l}657.7^{* * *} \\
(244.3)\end{array}$ \\
\hline Tertiary education & $\begin{array}{c}1230.8^{* * * *} \\
(318.4)\end{array}$ & $\begin{array}{l}-389.5 \\
(758.9)\end{array}$ & $\begin{array}{l}1255.7^{* * *} \\
(323.7)\end{array}$ \\
\hline Inactive & $\begin{array}{c}632.5 \\
(706.7)\end{array}$ & $\begin{array}{l}-1468.1 \\
(1309.9)\end{array}$ & $\begin{array}{l}653.8 \\
(710.3)\end{array}$ \\
\hline Female*Inactive & $\begin{array}{l}-315.7 \\
(941.6)\end{array}$ & $\begin{array}{c}1321.0 \\
(1460.7)\end{array}$ & $\begin{array}{l}-323.3 \\
(943.8)\end{array}$ \\
\hline Self-Employed & $\begin{array}{l}1239.2^{* * *} \\
(259.6)\end{array}$ & $\begin{array}{c}-54.4 \\
(618.0)\end{array}$ & $\begin{array}{l}1288.7^{* * *} \\
(263.5)\end{array}$ \\
\hline \# working years & $\begin{array}{c}14.3 \\
(15.4)\end{array}$ & $\begin{array}{l}-25.5 \\
(26.3)\end{array}$ & $\begin{array}{c}16.2 \\
(15.5)\end{array}$ \\
\hline Medium city & $\begin{array}{c}322.2 \\
(318.8)\end{array}$ & $\begin{array}{l}746.0^{*} \\
(435.8)\end{array}$ & $\begin{array}{l}253.6 \\
(318.4)\end{array}$ \\
\hline Large city & $\begin{array}{l}-181.6 \\
(247.4)\end{array}$ & $\begin{array}{c}425.5 \\
(408.8)\end{array}$ & $\begin{array}{l}-243.3 \\
(246.5)\end{array}$ \\
\hline Mega city & $\begin{array}{l}-379.0 \\
(415.7)\end{array}$ & $\begin{array}{c}-63.0 \\
(557.5)\end{array}$ & $\begin{array}{l}-424.4 \\
(416.8)\end{array}$ \\
\hline North Italy & $\begin{array}{l}-653.8^{* *} \\
(263.5)\end{array}$ & $\begin{array}{c}-1307.3^{* * *} \\
(431.6)\end{array}$ & $\begin{array}{l}-690.6^{* * *} \\
(264.3)\end{array}$ \\
\hline Centre Italy & $\begin{array}{l}-199.8 \\
(284.6)\end{array}$ & $\begin{array}{l}-2998.0^{* * *} \\
(1152.8)\end{array}$ & $\begin{array}{l}-140.7 \\
(281.2)\end{array}$ \\
\hline$\#$ hh members $<=25$ & $\begin{array}{l}-148.4 \\
(126.8)\end{array}$ & $\begin{array}{l}-105.4 \\
(178.5)\end{array}$ & $\begin{array}{l}-147.3 \\
(127.2)\end{array}$ \\
\hline$\#$ hh members $>25$ & $\begin{array}{c}5.4 \\
(208.3)\end{array}$ & $\begin{array}{c}316.5 \\
(300.5)\end{array}$ & $\begin{array}{c}4.0 \\
(208.7)\end{array}$ \\
\hline Offspring outside hh & $\begin{array}{l}-162.3 \\
(291.7)\end{array}$ & $\begin{array}{l}-39.9 \\
(394.1)\end{array}$ & $\begin{array}{l}-178.0 \\
(292.5)\end{array}$ \\
\hline Log(Ind Income) & $\begin{array}{c}1024.1^{* * *} \\
(264.1)\end{array}$ & $\begin{array}{c}-35.3 \\
(508.9)\end{array}$ & $\begin{array}{l}997.4^{* * *} \\
(267.8)\end{array}$ \\
\hline IndIncome/Wealth & $\begin{array}{l}-0.1 \\
(0.1)\end{array}$ & $\begin{array}{c}0.1 \\
(0.2)\end{array}$ & $\begin{array}{l}-0.1 \\
(0.1)\end{array}$ \\
\hline IndIncome/hhIncome & -760.8 & 2004.7 & -786.0 \\
\hline
\end{tabular}


(571.1)

Risk Adverse

30.7

(208.3)

Home-owner

$892.6^{* * *}$

(290.7)

Hold stocks

Financial literacy (0-3)

$419.4^{* * *}$

(137.1)
(1315.9)

(510.8) (209.5) $900.9^{* * *}$ (292.6) $744.5^{* *}$ (331.3)

\section{Constant}

$9519.4^{* * *}$

$-26676.8^{* * *}$

(4427.3)

$-34856.6^{* * *}$

$-25271.7^{* * *}$

(5390.6)

\begin{tabular}{|c|c|c|c|}
\hline $\begin{array}{l}\text { sigma } \\
\text { Constant }\end{array}$ & $\begin{array}{c}4004.8^{* * *} \\
(471.1)\end{array}$ & & $\begin{array}{c}4018.1^{* * *} \\
(476.7)\end{array}$ \\
\hline Observations & 6793 & 6793 & 6793 \\
\hline Pseudo $\mathrm{R}^{\wedge} 2$ & 0.02199 & & 0.02138 \\
\hline Wald exogeneity p-value & & 0.00002 & \\
\hline
\end{tabular}

Standard errors in parentheses

Clustered SE at household level

Source: SHIW 2010-2012, individuals aged 25-65, household head and partner

Upper and lower 0.5 percentile of individual income dropped

Excluded instruments for financial literacy: father and mother manager, entrepreneur, self-employed

Note: we have also estimated a the two-step Heckman model. In the second stage, the coefficient of the Mill's ratio was not statistically different from zero.

Note: ivtobit provides a Wald test for the exogeneity of Financial literacy, since the test statistic is significant, we can reject the null hypothesis of no endogeneity. Thus, the IV strategy is appropriate here.

Note: age^ 2 has been divided by 1000

${ }^{*} p<0.10,{ }^{* *} p<0.05,{ }^{* * *} p<0.01$ 


\section{(1)}

FE - All
(2)

FE - Male
(3)

(4)

FE - Female FE - All 2012-

\begin{tabular}{|c|c|c|c|c|}
\hline \multicolumn{5}{|l|}{ Female } \\
\hline \multirow[t]{2}{*}{ Age hh Head } & $0.0285^{* *}$ & 0.0212 & $0.0342^{* *}$ & 0.0490 \\
\hline & $(0.0124)$ & $(0.0165)$ & $(0.0158)$ & $(0.0380)$ \\
\hline \multirow[t]{2}{*}{ Age hh Head`2 } & $-0.2522^{* *}$ & -0.1844 & $-0.3359^{* *}$ & -0.4222 \\
\hline & $(0.1122)$ & $(0.1501)$ & $(0.1380)$ & $(0.3055)$ \\
\hline \multirow{2}{*}{ Age hh Head spouse } & -0.0032 & -0.0056 & 0.0001 & -0.0078 \\
\hline & $(0.0042)$ & $(0.0055)$ & $(0.0060)$ & $(0.0093)$ \\
\hline \multirow[t]{2}{*}{ Age hh Head spouse ${ }^{\wedge} 2$} & 0.0430 & 0.0622 & 0.0105 & 0.1111 \\
\hline & $(0.0605)$ & $(0.0814)$ & $(0.0823)$ & $(0.1275)$ \\
\hline \multirow[t]{2}{*}{ Living together } & -0.0709 & -0.0027 & -0.1555 & 0.1785 \\
\hline & $(0.0896)$ & $(0.1237)$ & $(0.1153)$ & $(0.1813)$ \\
\hline \multirow[t]{2}{*}{ Married } & 0.0135 & 0.0494 & -0.0260 & 0.2001 \\
\hline & $(0.0755)$ & $(0.1077)$ & $(0.0981)$ & $(0.1656)$ \\
\hline \multirow[t]{2}{*}{ High School } & -0.0375 & -0.0290 & -0.0520 & 0.0710 \\
\hline & $(0.0350)$ & $(0.0457)$ & $(0.0531)$ & $(0.1191)$ \\
\hline \multirow[t]{2}{*}{ Tertiary education } & -0.0392 & -0.0205 & -0.0552 & -0.2973 \\
\hline & $(0.0734)$ & $(0.1253)$ & $(0.0898)$ & $(0.1835)$ \\
\hline \multirow[t]{2}{*}{ Inactive but not retired } & 0.0397 & 0.0553 & 0.0087 & $0.1409^{* * *}$ \\
\hline & $(0.0483)$ & $(0.0489)$ & $(0.0359)$ & $(0.0534)$ \\
\hline \multirow[t]{2}{*}{ Female*Inactive } & -0.0108 & & & \\
\hline & $(0.0583)$ & & & \\
\hline \multirow[t]{2}{*}{ Self-Employed } & $0.0576^{*}$ & $0.0880^{* *}$ & -0.0085 & \\
\hline & $(0.0319)$ & $(0.0363)$ & $(0.0602)$ & \\
\hline \multirow[t]{2}{*}{ \# working years } & 0.0008 & 0.0010 & 0.0009 & $0.0064^{* *}$ \\
\hline & $(0.0010)$ & $(0.0012)$ & $(0.0016)$ & $(0.0027)$ \\
\hline \multirow{2}{*}{ Medium city } & 0.0549 & 0.0870 & 0.0380 & -0.0797 \\
\hline & $(0.1081)$ & $(0.1707)$ & $(0.1341)$ & $(0.1931)$ \\
\hline \multirow[t]{2}{*}{ Large city } & 0.0671 & 0.1875 & -0.0224 & 0.1783 \\
\hline & $(0.1191)$ & $(0.1934)$ & $(0.1334)$ & $(0.2226)$ \\
\hline \multirow[t]{2}{*}{ Mega city } & 0.2786 & $0.4933^{* *}$ & -0.0244 & 0.3026 \\
\hline & $(0.1696)$ & $(0.2509)$ & $(0.1366)$ & $(0.2504)$ \\
\hline \multicolumn{5}{|l|}{ North Italy } \\
\hline \multicolumn{5}{|l|}{ Centre Italy } \\
\hline \multirow[t]{2}{*}{$\#$ hh members $<=25$} & -0.0031 & 0.0024 & -0.0071 & -0.0000 \\
\hline & $(0.0131)$ & $(0.0162)$ & $(0.0192)$ & $(0.0329)$ \\
\hline \multirow[t]{2}{*}{ \# hh members $>25$} & 0.0164 & $0.0448^{* *}$ & -0.0154 & 0.0399 \\
\hline & $(0.0145)$ & $(0.0198)$ & $(0.0196)$ & $(0.0338)$ \\
\hline \multirow[t]{2}{*}{ Offsprings outside hh } & 0.0135 & 0.0181 & 0.0094 & 0.0245 \\
\hline & $(0.0161)$ & $(0.0210)$ & $(0.0219)$ & $(0.0483)$ \\
\hline \multirow[t]{2}{*}{ Log(Ind Income) } & $0.0374^{* * *}$ & $0.0545^{* * *}$ & 0.0201 & 0.0202 \\
\hline & $(0.0125)$ & $(0.0159)$ & $(0.0182)$ & $(0.0421)$ \\
\hline \multicolumn{5}{|l|}{ IndIncome/Wealth } \\
\hline IndIncome/hhIncome & 0.0071 & 0.0107 & 0.0072 & 0.1411 \\
\hline
\end{tabular}




\begin{tabular}{lcccc} 
& $(0.0378)$ & $(0.0465)$ & $(0.0688)$ & $(0.1008)$ \\
Risk Adverse & 0.0147 & 0.0114 & 0.0183 & 0.0009 \\
TFR to pension & $(0.0095)$ & $(0.0119)$ & $(0.0131)$ & $(0.0201)$ \\
& $0.3696^{* * *}$ & $0.3464^{* * *}$ & $0.3974^{* * *}$ & $0.3792^{* * *}$ \\
Home-owner & $(0.0221)$ & $(0.0289)$ & $(0.0295)$ & $(0.0277)$ \\
& $-0.0604^{* * *}$ & $-0.0633^{* *}$ & $-0.0628^{* *}$ & $-0.1332^{* *}$ \\
Hold stocks & $(0.0210)$ & $(0.0252)$ & $(0.0302)$ & $(0.0546)$ \\
& $0.0616^{* * *}$ & $0.0675^{* * *}$ & $0.0548^{* *}$ & $0.0862^{* *}$ \\
Constant & $(0.0201)$ & $(0.0257)$ & $(0.0239)$ & $(0.0405)$ \\
& $-1.0349^{* * *}$ & $-1.1067^{* *}$ & $-0.8680^{*}$ & -1.6567 \\
Time dummies & $(0.3588)$ & $(0.4862)$ & $(0.4720)$ & $(1.2028)$ \\
\hline Observations & Yes & Yes & Yes & Yes \\
$\mathrm{R}^{\wedge} 2$ & 20771 & 11696 & 9075 & 6895 \\
WithinR^2 & 0.15308 & 0.14907 & 0.16611 & 0.18622 \\
OverallR^2 & 0.15422 & 0.15104 & 0.16859 & 0.18906 \\
\hline S & 0.07169 & 0.05070 & 0.10816 & 0.04902 \\
\hline
\end{tabular}

Standard errors in parentheses

Clustered SE at household level

Source: SHIW 2004-2012, individuals aged 25-60, household head and partner

Note: age ${ }^{\wedge} 2$ has been divided by 1000

${ }^{*} p<0.10,{ }^{* *} p<0.05,{ }^{* * *} p<0.01$ 


\section{Latest CeRP Working Papers}

\begin{tabular}{|c|c|}
\hline $\mathrm{N}^{\circ} 156 / 16$ & $\begin{array}{l}\text { Elisa Luciano } \\
\text { Mariacristina Rossi } \\
\text { Dario Sansone }\end{array}$ \\
\hline $\mathrm{N}^{\circ} 155 / 16$ & Claudio Morana \\
\hline $\mathrm{N}^{\circ} 154 / 15$ & Vincenzo Andrietti \\
\hline $\mathrm{N}^{\circ} 153 / 15$ & $\begin{array}{l}\text { Donatella Baiardi } \\
\text { Claudio Morana }\end{array}$ \\
\hline $\mathrm{N}^{\circ} 152 / 15$ & $\begin{array}{l}\text { Ewa Gałecka-Burdziak } \\
\text { Marek Góra }\end{array}$ \\
\hline $\mathrm{N}^{\circ} 151 / 15$ & $\begin{array}{l}\text { Margherita Borella } \\
\text { Flavia Coda Moscarola }\end{array}$ \\
\hline $\mathrm{N}^{\circ} 150 / 15$ & Anna Lo Prete \\
\hline $\mathrm{N}^{\circ} 149 / 15$ & $\begin{array}{l}\text { Flavia Coda Moscarola } \\
\text { Ugo Colombino } \\
\text { Francesco Figari } \\
\text { Marilena Locatelli }\end{array}$ \\
\hline $\mathrm{N}^{\circ} 148 / 15$ & $\begin{array}{l}\text { Flavia Coda Moscarola } \\
\text { Elsa Fornero } \\
\text { Steinar Strøm }\end{array}$ \\
\hline $\mathrm{N}^{\circ} 147 / 14$ & $\begin{array}{l}\text { Matteo Morini } \\
\text { Simone Pellegrino }\end{array}$ \\
\hline $\mathrm{N}^{\circ} 146 / 14$ & $\begin{array}{l}\text { Mariacristina Rossi } \\
\text { Eva Sierminska }\end{array}$ \\
\hline $\mathrm{N}^{\circ} 145 / 14$ & $\begin{array}{l}\text { Johannes G. Hoogeveen } \\
\text { Mariacristina Rossi } \\
\text { Dario Sansone }\end{array}$ \\
\hline $\mathrm{N}^{\circ} 144 / 14$ & Elsa Fornero \\
\hline $\mathrm{N}^{\circ} 143 / 14$ & $\begin{array}{l}\text { Kees de Vaan } \\
\text { Daniele Fano } \\
\text { Herialt Mens } \\
\text { Giovanna Nicodano }\end{array}$ \\
\hline $\mathrm{N}^{\circ} 142 / 14$ & $\begin{array}{l}\text { Elisabetta Cagna } \\
\text { Giulio Casuccio }\end{array}$ \\
\hline $\mathrm{N}^{\circ} 141 / 14$ & $\begin{array}{l}\text { Massimo Baldini } \\
\text { Costanza Torricelli } \\
\text { Maria Cesira Urzì Brancati }\end{array}$ \\
\hline $\mathrm{N}^{\circ} 140 / 14$ & $\begin{array}{l}\text { Cecilia Boggio } \\
\text { Elsa Fornero } \\
\text { Henriette Prast } \\
\text { Jose Sanders }\end{array}$ \\
\hline$N^{\circ} 139 / 14$ & $\begin{array}{l}\text { Laura Bianchini } \\
\text { Margherita Borella }\end{array}$ \\
\hline
\end{tabular}

Financial Inclusion and Life Insurance Demand; Evidence from Italian households

The US\$/€ exchange rate: Structural modeling and forecasting during the recent financial crises

Auto-enrollment, Matching, and Participation in 401(k) Plans

Financial deepening and income distribution inequality in the euro area

The impact of easy and early access to old-age benefits on exits from the labour market: a macro-micro analysis

The 2011 Pension Reform in Italy and its Effects on Current and Future Retirees

Labour market institutions and household consumption insurance within OECD countries

Shifting Taxes from Labour to Property. A Simulation under Labour Market Equilibrium

Absenteeism, Pension Reforms and Grandmothers

Personal Income Tax Reforms: a Genetic Algorithm Approach

Single again? Asset and portfolio changes due to widowhood shock

Drivers of performance in primary education in Togo

Economic-financial literacy and (sustainable) pension reforms: why the former is a key ingredient for the latter

A Reporting Standard for Defined Contribution Pension Plans

Equally-weighted Risk Contribution Portfolios: an empirical study using expected shortfall

Family ties: occupational responses to cope with a household income shock

Seven Ways to Knit Your Portfolio: Is Investor Communication Neutral?

Cognitive Functioning and Retirement in Europe

The full series is available at: http://www.cerp.carloalberto.org/category/publications/working-papers/ 